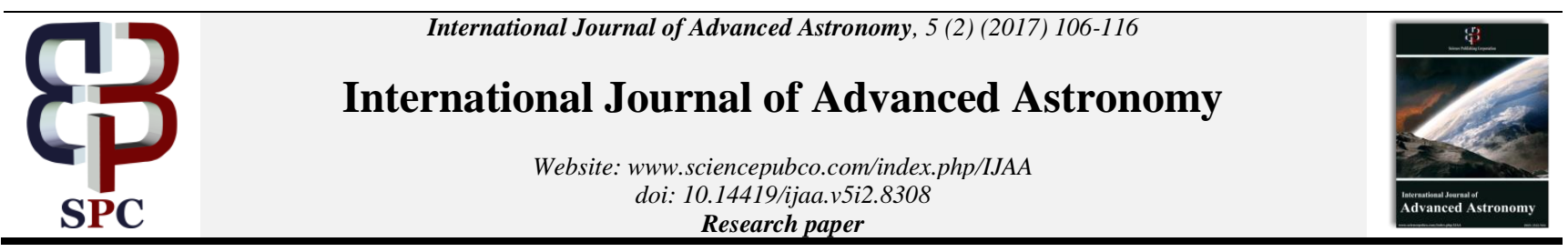

\title{
Performance evaluation of existing sunshine-based computing models for estimating global solar radiation at Lagos, Nigeria
}

\author{
Nwokolo Samuel Chukwujindu *, Ogbulezie Julie C. \\ Department of Physics, Faculty of Physical Sciences, University of Calabar, Nigeria, P.O. Box 2892, Calabar, Nigeria \\ *Corresponding author E-mail: nwokolosc@stud.unical.edu.ng
}

\begin{abstract}
Several empirical models have been fitted in literature for estimating global solar radiation across the globe in order to produce global solar radiation data and also as a baseline for further scientific and environmental research without the substantial cost of instrumental network that would otherwise be needed. However, peers and researchers have reported that the most commonly employed parameter for predicting global solar radiation is sunshine duration as a result of its availability and simplicity in course of measurement globally. In this research, the author considered the performance of 63 sunshine-based models for the prediction of global solar radiation at Lagos, Nigeria. Numerous models are found unreliable for use in this location, and others vary in performance. On the whole, the best model was identified due to its values of statistical indicators.
\end{abstract}

Keywords: Global Solar Radiation; Sunshine Based Models; Statistical Indicators; Tropical Rainforest Zone; Lagos.

\section{Introduction}

Solar energy has evolved to become a topical issue globally because of its enormous significance in many industries and application areas such as exciting electrons in a photovoltaic cell, solar heating, solar thermal energy, solar architecture, molten salt power plants and supplying energy to natural processes like photosynthesis as shown in equation 1 .

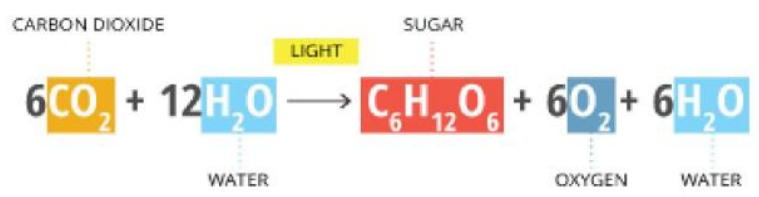

Solar energy is well known as the source of life on earth. It supplies heat to the atmosphere and lands, generates its winds, drives the water cycle, warms the oceans, grows the plants, feeds the animals, and even generates fossil fuels.

Increase in population and growing demand in urban and rural areas with the corresponding development in science and technology, changes in rural scenario and agricultural practices has necessitated the high demand of alternative (renewable) energy for both developing and developed nations across the globe.

The abundance of solar energy availability qualifies it as a highly appealing source of electricity irrespective of the efforts of researches, scientists, government as well as non-governmental agencies (NGOs) so far to exploiting this unique energy via numerous technologies, solar energy potential is fundamentally in exploited yet. The quantity of energy emitted by sun is so enormous that in case of converting only $0.1 \%$ of the solar energy reaching the earth surface to electricity with the efficiency of $10 \%$, the output power would be $17,300 \mathrm{GW}$, which is 7 times higher than the global average momentary electricity consumption in 2012 [1-3].

Solar energy is primarily derived from solar radiation reaching the surface of the earth. It is an electromagnetic radiation of varying wavelengths ranging from $10^{8} \mu \mathrm{m}$ ( $\mu$ rays) to $10^{8} \mu \mathrm{m}$ (radio wave) [4]. It serve as a baseline for estimating and understanding solar radiation parameters such as diffuse solar radiation, direct solar radiation, ground reflected, reference evapotranspiration, crop evaporation and actual evaporation.

A good working knowledge of solar radiation is needed for many application such as exciting electrons in an photovoltaic cell and supplying energy to natural processes like photosynthesis, thermal system and photovoltaic [5]; meteorology, climatology, radiation and energy budgets, water treatment processes, heating and natural lighting, agriculture and forestry, and use in renewable energy; air conditioning engineers and energy-conscious designers of building [6-7].

Solar radiation varies from one climate and geographical site to another. It is function of meteorological parameters such as evaporation, effects of cloudiness, relative humidity, precipitation, temperature, sunshine duration, extraterrestrial solar radiation, and reflection of the environs; geographical parameters such as latitude, longitude and elevation of the site; geometrical factors such as azimuth angle, sun azimuth angle; astronomical parameters like solar constant, earth-sun distance, solar declination and hour angle; physical parameters such as scattering air molecules, water vapour content, scattering of dust and other atmospheric constituents like $\mathrm{O}_{2}, \mathrm{~N}_{2}, \mathrm{CO}_{2}$, and $\mathrm{O}$ [4], [8].

Global solar radiation has been measured and quantify in numerous locations in Nigeria and across the globe using a variety of measurement instrument and techniques. These assessments have involved direct measurement with meteorological measuring instrument such as Eppley pyranometer and satellite remote-sensing instrument such as Moderate-Resolutoin Imaging Spectroradiometer (MODIS) products, and meteosat-images etc. 
As a result of cost implication, maintenance, expertise involved in ground measurement and satellite-derived data especially in rural and developing locations in Nigeria and the world at large, numerous estimation models employing empirical, artificial neutral network, adaptive neural fuzzy inference system approach, autoregressive Moving Average, support vector machine, genetic programming etc. had been proposed by solar energy researchers that can produce global solar radiation data without the substantial cost of the instrumental network that would otherwise be needed [912].

Angstrom [13] developed the first empirical model for estimating average daily global solar radiation to average clear-sky daily global radiation at a particular location with the sunshine duration fraction. In order to correct the anomalies in the definition of a clear sky, other researchers Prescott [14] have put the correlation in a more convenient form by substituting the clear-sky radiation with average daily extraterrestrial radiation on horizontal surface. Since last decades, several solar energy researchers have employed Angstrom-Prescott model globally as a baseline further developing empirical models for estimating global solar radiation using the same parameter, other meteorological parameters, geographical parameters, geometrical parameters and astronomical parameters that will best fit the local climate of their interest.

Therefore, the main purpose of this research is to determine the performance and reliability of sixty three sunshine-based computing models for estimating global solar radiation at Lagos, Nigeria. Thus this research will determine greatly numerous functional forms of sunshine -based models employed for estimating global solar radiation.

\section{Study area}

Lagos is located in Nigeria between latitude $3.33{ }^{\circ} \mathrm{N}$ and longitude $6.58{ }^{\circ} \mathrm{E}$ with an altitude of $73 \mathrm{~m}$ above the sea level as shown in Fig. 1. Lagos has a tropical wet and dry climate with two distinct rainy seasons; the more intense season occurs between April and July, with a milder one from October to November. At the climax of the rainy season, the weather in Lagos is wet about half the time. Lagos experiences a dry season (when it rains less than two days per month) during August and September, as well as between December and March, accompanied by Harmattan winds from the Sahara Desert, which are at their strongest from December to early February. The temperature range in Lagos is fairly small, generally staying between a high of $33^{\circ} \mathrm{C}$ and low of $21^{\circ} \mathrm{C}$. The hottest month is March, when average daytime temperatures reach $29^{\circ} \mathrm{C}$, while July is the coldest month with an average temperature of $25^{\circ} \mathrm{C}$.

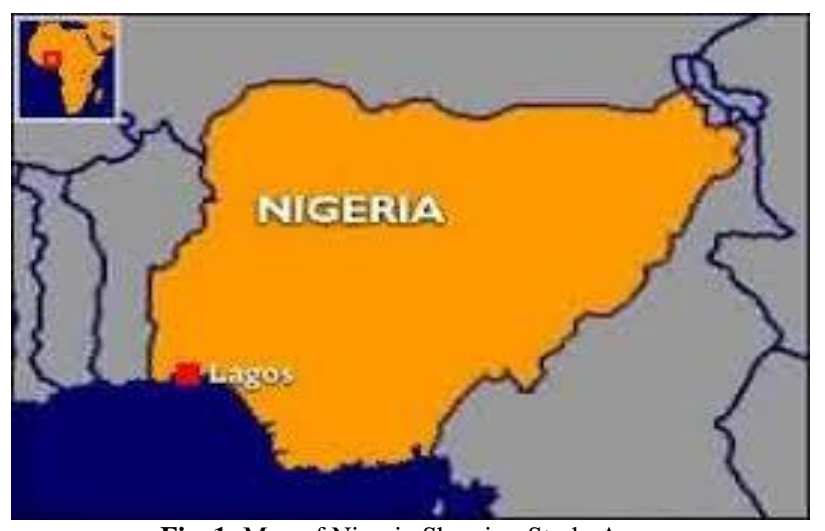

Fig. 1: Map of Nigeria Showing Study Area.

\section{Materials and methods}

\subsection{Data acquisition}

The long term monthly mean daily global solar radiation and sunshine duration for the period of 43 years (1970-2012) were ob- tained from the Nigerian Meteorological Agency (NIMET), Oshodi, Lagos. The global solar radiation data were captured using Gun-Bellani distillate (measured in milliliters) and were converted into $\mathrm{MJm}^{-2} \mathrm{day}^{-1}$ using a conversion factor of $1.216 \mathrm{H}_{\mathrm{GB}}$ (where $\mathrm{H}_{\mathrm{GB}}$ is the Gun-Bellani reading) proposed by Ododo [15].

The Gun-Bellani distillate solar radiation integrator provides a time integrated reading of radiation falling on a black body by measuring the volume of the liquid distilled in a receiving graduated tube. It is normally calibrated against standard solar radiation recorder such as pyranometer, pyrheliometer to obtain accurate result associated with the respective actinometer. In developing countries like Nigeria, the Gun-Bellani distillate solar radiation integrator low cost, simple observation procedure and absence of any replaceable mechanical and electronic part favours it application for weather data assessment across a number of experimental stations.

The daily sunshine hours was measured employing the Campbell Stokes sunshine recorder which comprises a glass sphere mounted concentrically in a section of a spherical bowl. The length of the burn trace left on the card represents the sunshine duration in hour. To generate accurate readings, both the spherical part and the sphere should be designed so that the sphere can be accurately centered on it.

\subsection{Evaluation techniques}

The authors review the ISI Web of Science, Scopus, SciELO, and Google Scholar databases in order to obtain the models and its basic parameters for estimating global solar radiation. The following information was obtained from the published works: city, year of publication, functional forms, estimation models, performance of the models such as root mean square error, mean bias error, mean percentage error, coefficient of correlation, coefficient of determination etc. The accuracy of a model determines to a great extent its value for application. The three statistical indicators via mean bias error (MBE), mean percentage error (MPE) and root mean square error (RMSE) are often applied by solar energy researchers for evaluating the performance of a predictive model. MBE provides information on the long-term performance of model studied. RMSE provides information on the short-term performance of the model as it allows a term-by-term comparison of the actual deviation between the measured and estimated values. Generally, small values of MBE and RMSE are desirable [16-17]. MPE is an overall measure of estimation bias. It provides information regarding underestimation or overestimation of estimated data. A positive MPE value gives the average amount of overestimation in the predicted values and vice versa. Akpabio and Etuk [18] recommended low values of MPE for optimal performance of solar system. Thus, the models considered and selected in this paper are models with small values (close to zero) of MBE, MPE and RMSE as recommended by [16-18]. These relations are given as:

$$
\begin{aligned}
& M B E=\left[\sum_{i=1}^{N} \frac{(M i-E i)}{N}\right] \\
& M P E=\left[\sum_{i=1}^{N}\left(\frac{(M i-E i)^{2}}{M i}\right) \times 100\right] / N \\
& R M S E=\left[\sum_{i=1}^{N} \frac{(M i-E i)^{2}}{N}\right]^{1 / 2}
\end{aligned}
$$

Relative percentage error (e) was used to compare between the measured and estimated values for an individual month given as:

$$
e=\frac{{ }_{M i}-H_{E i}}{{ }_{M i}} \times 100
$$


Where $\mathrm{N}$ is the total number of observation, Mi is the $\mathrm{i}^{\text {th }}$ measured $\mathrm{H}$ values, Ei is the $\mathrm{i}^{\text {th }}$ estimated $\mathrm{H}$ values and other symbols retain their usual meaning.

\subsection{Fundamental requirements}

The basic parameters of sunshine duration fraction, daily extraterrestrial radiation on the horizontal surface $\left(\mathrm{H}_{\mathrm{o}}\right)$ is significant for the estimation of global solar radiation. Sunshine duration fraction is the ratio of actual sunshine duration to maximum possible sunshine duration expressed mathematically as:

$$
\begin{aligned}
S_{O} & =\frac{2}{15} \cos ^{-1}[\tan \delta \tan \varphi] \\
\delta & =23.45 \sin \left[\frac{360(n+284)}{365}\right]
\end{aligned}
$$

Where $\varphi$ is the latitude, $\delta$ is the solar declination given by Yaniktepe and Genc [5] and $n$ the number of days of the year starting from first January. The daily extraterrestrial solar radiation is the solar radiation intercepted by horizontal surface during a day without the atmosphere expressed theoretically as given by Yaniktepe and Genc [[5]:

$$
H_{O}=\frac{24}{\pi} I_{S C}\left(\begin{array}{l}
1 \\
+0.033 \cos \frac{360 n}{365}
\end{array}\right) \times\left(\begin{array}{c}
\cos \varphi \cos \delta \sin \omega_{S} \\
2 \pi \omega_{S} \\
+\frac{2}{360} \sin \varphi \sin \delta
\end{array}\right)
$$

Where the mean sunrise hour angle $\left(\omega_{s}\right)$ can be evaluated as:

$$
\omega_{S}=\cos ^{-1}[\tan \delta \tan \varphi]
$$

ISC is the solar constant and other symbols retain their usual meaning

\subsection{Empirical models}

In global solar radiation estimation, an empirical model relates global solar radiation with other easily measurable variables such as sunshine duration etc by employing concise mathematical functions. As a result of its simplicity and high operability, the empirical models are much more convenient for engineering applications. Numerous sunshine-based models have been reported in literature for estimating global solar radiation on the horizontal surface $(\mathrm{H})$ either on daily mean basis (DB) or monthly mean basis (MB) across the globe. In this paper, different functional forms of sunshine models were selected owing to the findings from peers and reviews that sunshine-based models reported the highest influence on models performance accuracy for estimating global solar radiation across the globe compared to other meteorological and atmospheric parameters employed. This radiometric model pioneered by Angstrom [13] and modified by Prescott [14] and other researchers have been applied by countless number of solar radiation researchers for estimating the monthly mean daily global solar radiation on the horizontal surface for several stations within Nigeria and across the globe by determining the empirical constants $(\mathrm{a}, \mathrm{b})$ of equation (10) employing meteorological parameters of the site of interest. This relation is given as follows:

$$
\frac{H}{H_{o}}=a+b\left(\frac{S}{S_{o}}\right)
$$

Where $\mathrm{a}$ and $\mathrm{b}$ are the empirical constants, $\mathrm{S}$ is the measure of sunshine duration and $S_{o}$ is the daily maximum possible sunshine duration.
Apart from Angstrom-Prescott type model, those fitted by Rietveld [19] seems to be universally applicable. However, Akpabio et al. [20] and Falayi and Rabiu [21] employed empirical model for estimating monthly mean daily global solar radiation on the horizontal surface with fraction of sunshine duration for several locations in Nigeria; the result showed better performance and high accuracy in the fitted sites as compared to reported models in literature that seems to be universally applicable. As a result, the author employed greater number of estimation models proposed for Nigerian environment since global solar radiation depends grossly on the climate and geographical location of the site. Numerous sunshine-based models employing Angstrom-Prescott type model and other modified (exponential form, logarithm form, second order, third order and power form) models applied for estimating global solar radiation in literature as presented in Table 1.

\subsubsection{Group 1 (linear models)}

Empirical models from this group are parameterized as the firstorder polynomial function of the relative sunshine-based model proposed by Angstrom [13] and Prescott [14] as shown in equation 10. Thus, the empirical coefficients a and $\mathrm{b}$ differ depending on the result reported for the first-order regression analysis.

\subsubsection{Group 2 (second-order models)}

The empirical models from this group employed second order Angstrom-Prescott type model for estimating global solar radiation. The empirical model has the form:

$$
\frac{H}{H_{o}}=a+b\left(\frac{S}{S_{o}}\right)+c\left(\frac{S}{S_{o}}\right)^{2}
$$

\subsubsection{Group 3 (third-order models)}

In this group, the monthly mean of the daily global solar radiation employed third-order Angstrom-Prescott type model for estimating global solar radiation in the form:

$$
\frac{H}{H_{o}}=a+b\left(\frac{S}{S_{o}}\right)+c\left(\frac{S}{S_{o}}\right)^{2}+d\left(\frac{S}{S_{o}}\right)^{3}
$$

\subsubsection{Group 4 (other models)}

In this category, models that differ from group 1-3 are classified under this group. This includes exponential, non-linear, logarithm, power models etc as shown in Table 1. 
Table 1: Sunshine-Based Models for Estimating Monthly Mean Daily Global Solar Radiation

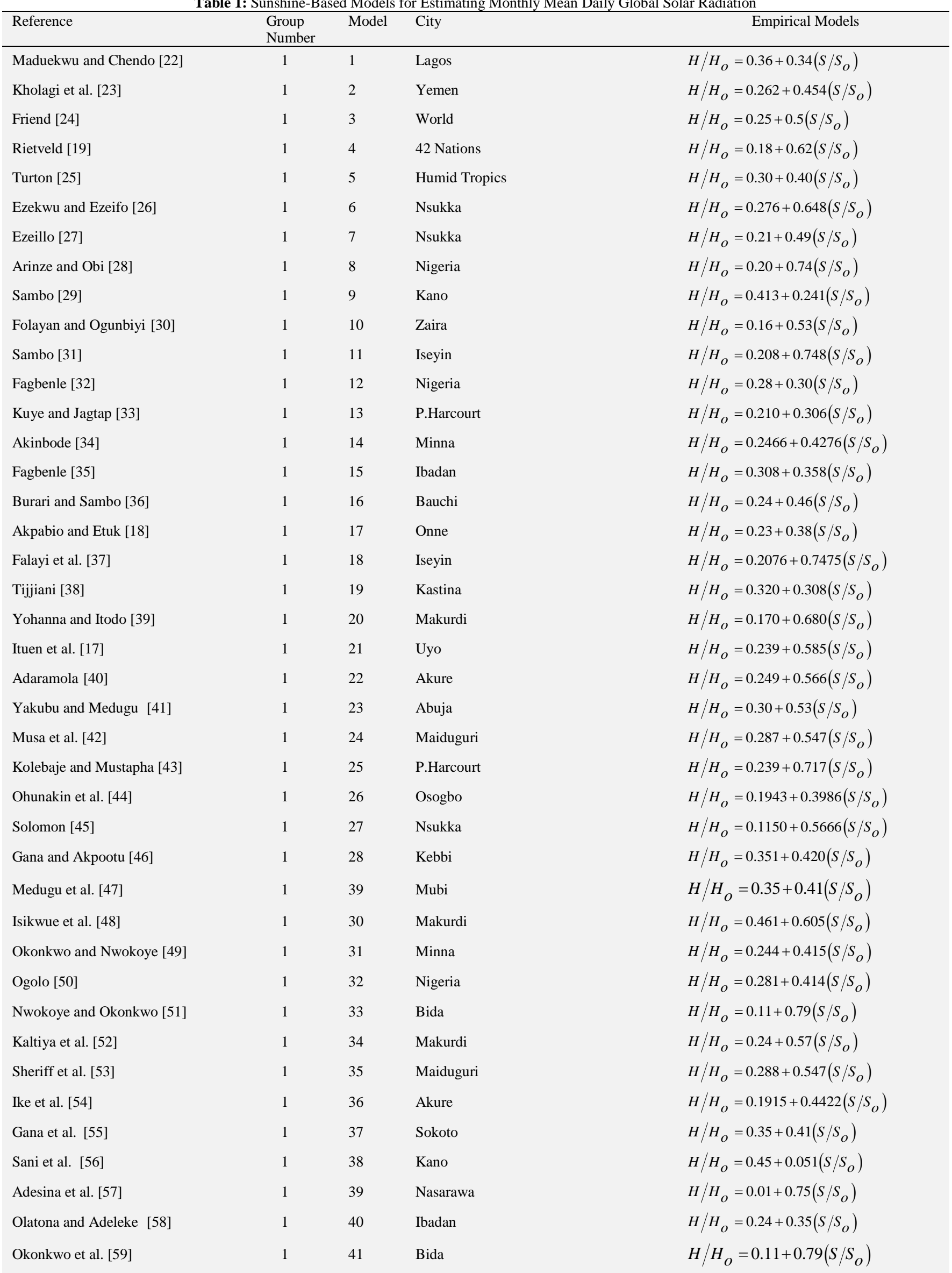

Table 1 (continued): Sunshine-Based Models for Estimating Monthly Mean Daily Global Solar Radiation 


\begin{tabular}{|c|c|c|c|c|}
\hline Innocent et al. [60] & 1 & 42 & Gusua & $H / H_{o}=0.2950+0.5317\left(S / S_{o}\right)$ \\
\hline Boluwaji and Onyedi [61] & 1 & 43 & Sokoto & $H / H_{o}=0.250+0.522\left(S / S_{o}\right)$ \\
\hline Okundamiya et al. [62] & 1 & 44 & Sokoto & $H / H_{O}=0.4785+0.2465\left(S / S_{o}\right)$ \\
\hline Ayodele and Ogunjuyigbo [63] & 1 & 45 & Ibadan & $H / H_{o}=0.27+0.24\left(S / S_{o}\right)$ \\
\hline Fagbenle [35] & 2 & 46 & Nigeria & $H / H_{o}=0.375+0.128\left(S / S_{o}\right)+0.660\left(S / S_{o}\right)^{2}$ \\
\hline Udo [64] & 2 & 47 & Ilorin & $H / H_{o}=0.053+1.280\left(S / S_{o}\right)+0.830\left(S / S_{o}\right)^{2}$ \\
\hline Akpabio et al. [20] & 2 & 48 & Onne & $H / H_{o}=0.147+1.250\left(S / S_{o}\right)-1.416\left(S / S_{o}\right)^{2}$ \\
\hline Ohunakin [44] & 2 & 49 & Osogbo & $H / H_{o}=0.0836+1.0054\left(S / S_{o}\right)-0.7646\left(S / S_{o}\right)^{2}$ \\
\hline Ayodele and Ogunjuyigbe [63] & 2 & 50 & Ibadan & $H / H_{o}=0.26+0.34\left(S / S_{o}\right)-0.11\left(S / S_{o}\right)^{2}$ \\
\hline Maduekwu and Chendo [22] & 2 & 51 & Lagos & $H / H_{o}=0.18+1.16\left(S / S_{o}\right)-0.91\left(S / S_{o}\right)^{2}$ \\
\hline Lewis [65] & 3 & 52 & Tennessee & $H / H_{o}=0.81-3.34\left(S / S_{o}\right)+7.38\left(S / S_{o}\right)^{2}-4.51\left(S / S_{o}\right)^{3}$ \\
\hline Trahran and Sari [66] & 3 & 53 & Turkey & $H / H_{o}=0.1520+1.1334\left(S / S_{o}\right)-1.1126\left(S / S_{o}\right)^{2}+0.4516\left(S / S_{o}\right)^{3}$ \\
\hline Burari et al. [67] & 3 & 54 & Maiduguri & $H / H_{o}=0.171+0.026\left(S / S_{o}\right)+2.01\left(S / S_{o}\right)^{2}-1.64\left(S / S_{o}\right)^{3}$ \\
\hline Ayodele and Ogunjuyigbo [63] & 3 & 55 & Ibadan & $H / H_{o}=0.25+0.38\left(S / S_{o}\right)-0.21\left(S / S_{o}\right)^{2}+0.074\left(S / S_{o}\right)^{3}$ \\
\hline Okundamiya et al. [62] & 4 & 56 & Abuja & $H / H_{O}=0.7349(1 / S)$ \\
\hline Gana and Akpootu [55] & 5 & 57 & Kebbi & $H / H_{O}=0.747\left(1 / S / S_{o}\right)$ \\
\hline Gana and Akpootu [56] & 6 & 58 & Kebbi & $H / H_{o}=0.392\left(S / S_{o}\right)^{0.714}$ \\
\hline Ayodele and Ogunjuyigbo [63] & 7 & 59 & Ibadan & $H / H_{o}=0.14 e^{0.15\left(S / S_{o}\right)}$ \\
\hline Ayodele and Ogunjuyigbo [63] & 8 & 60 & Ibadan & $H / H_{o}=0.46+0.17 \log \left(S / S_{o}\right)$ \\
\hline Togrul and Togrul [68] & 9 & 61 & Turkey & $H / H_{o}=0.46+0.17 \operatorname{In}\left(S / S_{o}\right)$ \\
\hline Ulgen and Hepbasli [69] & 10 & 62 & Turkey & $H / H_{O}=-0.0271+0.3096 \exp \left(S / S_{o}\right)$ \\
\hline Glover and McCulloch [70] & 11 & 63 & World & $H / H_{o}=0.29 \cos (\varphi)+0.52\left(S / S_{o}\right)$ \\
\hline
\end{tabular}

\section{Results and discussion}

\subsection{Variation of Atmospheric Parameters}

The observed values of sunshine duration (S), global solar radiation on a horizontal surface $(\mathrm{H})$, calculated values of monthly mean extraterrestrial solar radiation $\left(\mathrm{H}_{\mathrm{o}}\right)$, monthly mean dayligh hour $\left(\mathrm{S}_{\mathrm{o}}\right)$, clearness index $\left(\mathrm{H} / \mathrm{H}_{\mathrm{o}}\right)$ and sunshine fraction $\left(\mathrm{S} / \mathrm{S}_{\mathrm{o}}\right)$ are presented in Table 2. Seasonal and monthly variations are observed in both the observed global solar radiation and sunshine duration. Lower values of these parameters are generally observed in the rainy season (April to October) when compared to the dry season (November to March). The maximum values of the monthly mean daily sunshine duration and the monthly mean daily global solar radiation on a horizontal surface in this site are 6.15 hours and $16.40 \mathrm{MJm}^{-2} \mathrm{day}^{-1}$ in the months of December and April respectively; while the minimum values occur in August as 3.24 hours and $9.56 \mathrm{MJm}^{-2} \mathrm{day}^{-1}$ with a corresponding overall mean values of 4.98 hours and $12.97 \mathrm{MJm}^{-2} \mathrm{day}^{-1}$ for the monthly mean daily sunshine hours and global solar radiation on a horizontal surface respectively. These months of occurrence coincides with the dry and rainy seasons respectively at the site. High values of sunshine duration and global solar radiation obtained during the dry season can be attributed to the presence of low smog, relative humidity, cloud cover, low absorption of diffuse solar radiation and near infrared radiation in the solar spectrum, prolonged dry season with associated latitude and prevailing cloudiness and as- sociated atmospheric moisture with the movement of the Hadley cell circulation system along the equatorial line during this period over Lagos and its environs thereby enhancing global solar radiation and clearness index received in the site; while the low values of sunshine duration and global solar radiation obtained during the rainy season could be due to relatively higher cloud cover, relative humidity, prolonged rainy season and more absorption of diffuse and near infrared radiation in the solar spectrum thereby producing low magnitude of global solar radiation received in the site. These trends are similar to the report of several solar energy researchers in the region-tropical rainforest zone in Nigeria [22], [35], [37], [40], [44], [62-63].

\subsection{Classification}

\subsubsection{Clearness index}

The monthly mean clearness index designates the percentage depletion by the sky of the incoming global solar radiation and therefore indicates both the level of availability of solar radiation and changes in the atmospheric condition in a given locality. The prevailing clearness index varied between the range of $0.26-0.44$ between the months of April to October in the rainy season and $0.40-0.42$ between the months of November to March in the dry Season with an annual value of 0.36 as shown in Table 2 . These values are comparable to the report in the same region in Nigeria [17-18], [22], [33], [35], [37], [44]. Using the weather classification proposed by Iqbal [71] which are: (1) heavily overcast weath- 
er (kt $\leq 0.4)$; (2) partly overcast weather $(0.6 \leq \mathrm{kt} \leq 0.4)$; and (3) clear weather $(\mathrm{kt} \geq 7)$. Judging from the overall mean value, the prevailing weather conditions of Lagos falls within the heavily overcast weather except during the months of November to April when weather condition can be considered as partly overcast weather. These indicate that the remarkable features of Lagos are dominance of heavily overcast weather. It was observed that global solar radiation increases temporarily with increase in the clearness index and then increases rapidly as the heavily overcast weather become clearer. This reveals that global solar radiation is optimally controlled by clearness index at Lagos, Nigeria.

\subsubsection{Sunshine fraction}

The monthly sunshine fraction is the ratio of actual sunshine duration to maximum possible sunshine duration which varies from one month to another because of the movement of the earth as shown in Table 2. Based on the sunshine fraction registered by World Meteorological Organization [72] which are: (1) cloudy sky $\left(0 \leq \mathrm{S} / \mathrm{S}_{o}<0.3\right)$, (2) scattered clouds sky $\left(0.3 \leq \mathrm{S} / \mathrm{S}_{\circ}<0.7\right)$, and $(30$ cloudy sky $\left(0.7 \leq \mathrm{S} / \mathrm{S}_{0} 1.0\right)$, the prevailing sunshine condition in Lagos is mainly scattered clouds sky except during June to September when it can be considered as cloudy sky condition. These reports are comparable to values registered in literature in the same tropical rain forest region of Nigeria [17-18], [22], [33], [35], [37], [44].

Table 2: Meteorological Data and Sunshine Values for Lagos

\begin{tabular}{lllllll}
\hline Month & $\mathrm{H}$ & $\mathrm{H}_{\mathrm{o}}$ & $\mathrm{H}_{/} \mathrm{H}_{\mathrm{o}}$ & $\mathrm{S}$ & $\mathrm{S}_{\mathrm{o}}$ & $\mathrm{S} / \mathrm{S}_{\mathrm{o}}$ \\
\hline January & 13.41 & 35.70 & 0.40 & 4.89 & 11.64 & 0.42 \\
February & 14.99 & 35.78 & 0.42 & 5.76 & 12.00 & 0.48 \\
March & 15.28 & 37.44 & 0.41 & 5.35 & 11.89 & 0.45 \\
April & 16.40 & 37.44 & 0.44 & 6.00 & 12.24 & 0.49 \\
May & 13.75 & 36.36 & 0.38 & 5.66 & 12.30 & 0.46 \\
June & 11.55 & 35.89 & 0.32 & 4.05 & 12.66 & 0.32 \\
July & 10.20 & 36.00 & 0.28 & 3.46 & 12.36 & 0.28 \\
August & 9.56 & 36.72 & 0.26 & 3.24 & 12.46 & 0.26 \\
September 11.14 & 37.08 & 0.30 & 3.60 & 12.00 & 0.30 \\
October & 12.64 & 36.00 & 0.35 & 5.42 & 11.78 & 0.46 \\
November & 13.67 & 34.06 & 0.40 & 6.12 & 11.77 & 0.52 \\
December & 13.01 & 32.80 & 0.40 & 6.15 & 11.60 & 0.53 \\
Average & 12.97 & 35.77 & 0.36 & 4.98 & 12.06 & 0.41 \\
\hline
\end{tabular}

$\mathrm{H}$ : measured global solar radiation $\left(\mathrm{MJm}^{-2} \mathrm{day}^{-1}\right), \mathrm{H}_{\mathrm{o}}$ : extraterrestrial solar radiation $\left(\mathrm{MJm}^{-2} \mathrm{day}^{-1}\right)$, $\mathrm{H} / \mathrm{H}_{\mathrm{o}}$ : clearness index, $\mathrm{S}$ : sunshine duration (hrs), $\mathrm{S}_{\mathrm{o}}$ : maximum possible sunshine duration (hrs), $\mathrm{S} / \mathrm{S}_{\mathrm{o}}$ : sunshine fraction

\subsection{Performance evaluation}

Table 4 outlines the relative percentage error for each model for each month during the year. Each model's performance varies from one month to another. This could be attributed to different climate and geographical information of the developed models. As a result of this climate and geographical parameter influence on global solar radiation, few models performed well in some months and reported higher values in other months.

The following models recorded relative percentage errors between -15 to $15 \%$ : in group 1 , model 10 with corresponding average value of relative percentage errors $-5.14 \%$, model 26 with an average relative percentage errors $0.00 \%$, model 27 with respective average relative percentage errors $3.45 \%$; In group 2, model 49 having average relative percentage errors $-1.39 \%$.

Within the relative percentage errors range of -20 to -15 and 15 to $20 \%$, only two (2) models from group 1 falls within the limit. These models include models 13 with average relative percentage errors $6.02 \%$ and model 36 having an average relative percentage errors $-4.13 \%$.
There are two (2) models with relative percentage errors ranging from -25 to -20 and 20 to 25 from group 1 and group 9. These models include model 39 with a corresponding relative percentage error $12.43 \%$ and model 61 with an average relative percentage error $15.54 \%$.

In Table 4, it was observed that relative percentage error ranging from -30 to -25 and 25 to $30 \%$ were reported from group 1 and group 3 . The models are as follows: model 7 with a corresponding average relative percentage error $-14.76 \%$; model 17 with an average relative percentage errors $-7.99 \%$; model 40 having an average relative percentage errors $-7.43 \%$; model 45 with an average relative percentage errors $-3.49 \%$; model 54 with an average relative percentage errors $-12.67 \%$ and $-5.18 \%$ reported for corresponding value of relative percentage errors for model 55 .

However, models having relative percentage errors above -30 to $25 \%$ and 25 to $30 \%$ were excluded due to their high errors exhibited for different months of the year. The models includes models $1-6,8-9,11-12,14-16,18-25,28-35,37-38,41-44$, and 46 from group 1; 47-48, and 50-51 from group 2; 52 and 53 in group 3; model 56 from group 4; model 57 in group 5; model 58 from group 6; model 59 from group 7; model 60 from group 8; model 62 from group 10; model 63 from group 11. On the whole, 49 models were excluded while 14 models falls with the relative percentage error range of -30 to $-15 \%$ and 15 to $30 \%$. Fig. 2 shows the monthly performance for these 14 models which recorded relative percentage errors between -30 and $-15 \%$.

In order to ascertain the annual performance of the models in different groups, regression analysis, MBEs, MPEs and RMSEs were employed as shown in Table 3. A close look at the 14 models (model 7, model 10, model 13, model 17, model 26, model 27, model 36 , model 39 , model 40, model 45 , model 49 , model 54 , model 55 and 61) selected using relative percentage errors analysis in Table 4, the readers will observed that MBE ranged from 0.15 to $0.17 \mathrm{MJm}^{-2} \mathrm{day}^{-1}$, MPE from -1.15 to $1.33 \%$ and RMSE from 0.02 to $0.60 \mathrm{MJm}^{-2} \mathrm{day}^{-1}$. It could also be observed that model 49, group 2, yielded the lowest value of these statistical indicators via $0.00 \mathrm{MJm}^{-2} \mathrm{day}^{-1}$ for MBE, $-0.03 \%$ for MPE, $0.02 \mathrm{MJm}^{-}$ ${ }^{2}$ day $^{-1}$ for RMSE, and coefficient of correlation 0.936 and the relationship with the measured data was presented in Fig. 3; followed by model 26 in group 1. Applying the recommendation of solar energy researchers for models used in estimating global solar radiation that small values of MBE, MPE and RMSE are required for optimal performance of a solar system [11-12], [16], [18] model 49 exhibited the best performance both among the entire models and among the models in group 2 (second-order polynomial of Angstrom-Prescott type model) fitted in Osogbo, Nigeria in the same tropical rainforest zone as Lagos. It is worthwhile to state emphatically that several solar energy researchers in Nigeria reported that the second-order polynomial of Angstrom-Prescott type model perform better than original first order model and third order models [20], [22], [35], [44], [63], [64]. This result also validates the background of this paper methodology by applying numerous models developed from Nigeria as global solar radiation solely depends on the local climate and geographical information in a give location. The result agrees favourably with report of several investigators across the globe that since most existing models are empirical in nature, they are likely to be specific to the atmospheric conditions under which they were developed, and thus may either over or underestimate measured data at other sites [73-76]. 


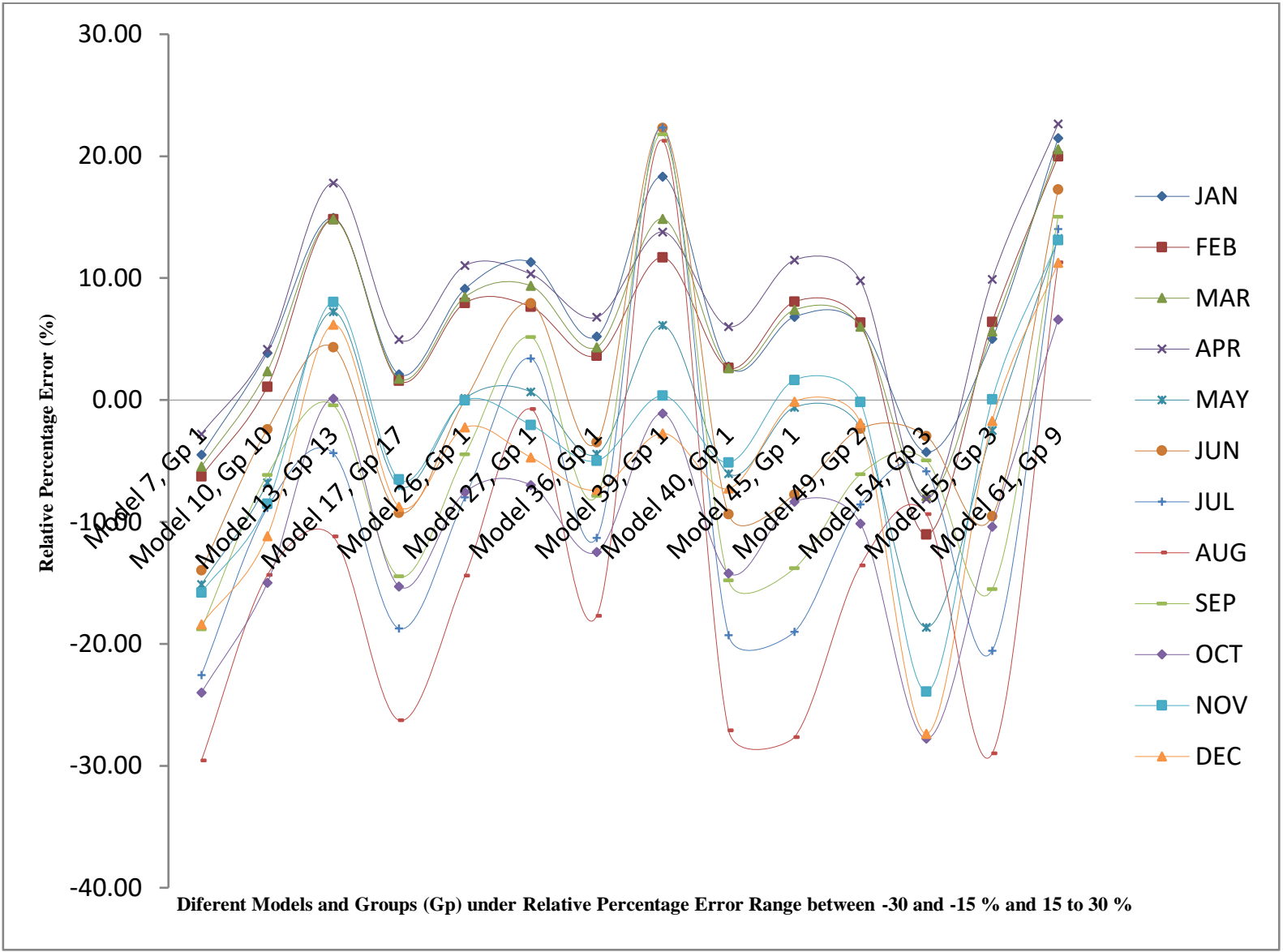

Fig. 2: Monthly Performance of Models with Relative Percentage Error (\%) With -30 and $-15 \%$ and 15 to $30 \%$.

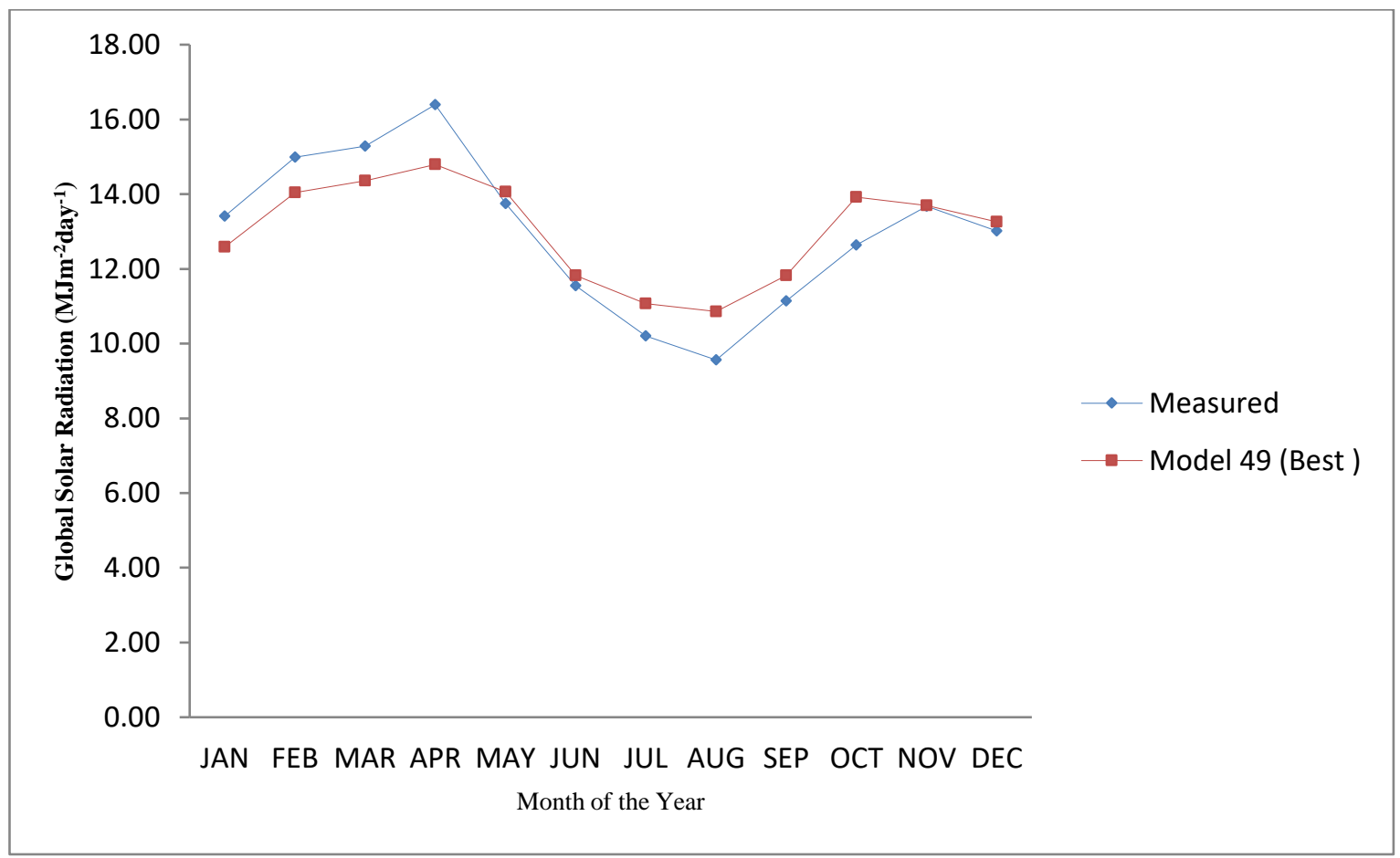

Fig. 3: Comparison Between Measured and Model 49 (Best Model) for Estimating Global Solar Radiation at Lagos, Nigeria. 
Table 3: Model Number, Group, Mean and Statistical Indicators for Measured and existing sunshine-based models at Lagos, Nigeria

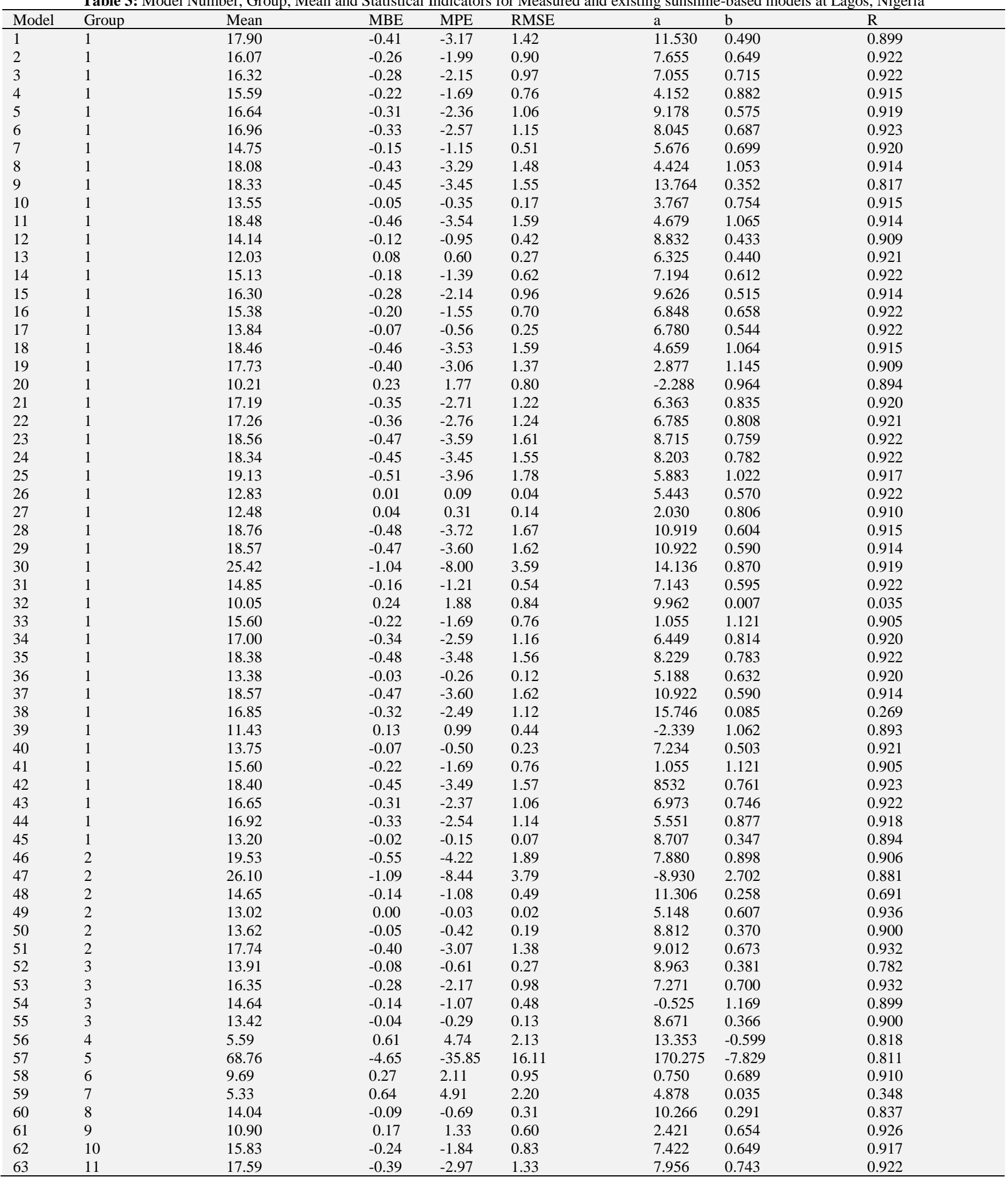

MBE: mean bias error $\left(\mathrm{MJm}^{-2} \mathrm{day}^{-1}\right)$, RMSE: root mean square error $\left(\mathrm{MJm}^{-2} \mathrm{day}^{-1}\right)$, MPE: mean percentage error $(\%)$, a and b are the regression constants between measured and the estimated values, $\mathrm{R}$ is the correlation coefficient between measured and estimated values 
Table 4: Relative Percentage Error for Each Model for Each Month and Average during the Year in Lagos, Nigeria

\begin{tabular}{|c|c|c|c|c|c|c|c|c|c|c|c|c|c|c|}
\hline \multirow[t]{2}{*}{ Model } & \multirow[t]{2}{*}{ Group } & \multicolumn{13}{|c|}{ Relative Percentage Error (\%) } \\
\hline & & Jan & Feb & Mar & Apr & May & Jun & Jul & Aug & Sep & Oct & Nov & Dec & Ave \\
\hline 1 & 1 & -26.34 & -24.87 & -25.67 & 20.26 & -36.55 & -45.65 & -60.66 & -72.19 & -53.74 & -47.06 & -33.72 & -36.18 & -40.24 \\
\hline 2 & 1 & -13.74 & -14.54 & -14.23 & -10.63 & -24.51 & -26.53 & -37.34 & -45.94 & -32.51 & -34.09 & -24.07 & -26.71 & -25.40 \\
\hline 3 & 1 & -15.58 & -16.94 & -16.36 & -13.04 & -26.93 & -27.38 & -37.65 & -45.93 & -33.11 & -36.70 & -27.04 & -29.83 & -27.21 \\
\hline 4 & 1 & -10.66 & -13.98 & -12.44 & -10.48 & -23.02 & -17.56 & -24.80 & -31.03 & -21.79 & -32.48 & -25.15 & -28.22 & -20.97 \\
\hline 5 & 1 & -17.59 & -17.42 & -17.59 & -13.27 & -27.99 & -32.97 & -45.41 & -55.14 & -39.76 & -37.84 & -26.54 & -29.07 & -30.05 \\
\hline 6 & 1 & -20.01 & -20.86 & -20.53 & -16.74 & -31.37 & -33.47 & -44.85 & -53.92 & -39.76 & -41.48 & -30.93 & -33.71 & -32.30 \\
\hline 7 & 1 & -4.48 & -6.25 & -5.46 & -2.79 & -15.14 & -13.96 & -22.54 & -29.57 & -18.80 & -24.00 & -15.78 & -18.41 & -14.76 \\
\hline 8 & 1 & -28.35 & -32.50 & -30.57 & -28.48 & -42.90 & -35.71 & -43.72 & -50.69 & -40.43 & -53.90 & -45.68 & -49.29 & -40.18 \\
\hline 9 & 1 & -29.21 & -26.18 & -27.74 & -21.28 & -38.53 & -52.27 & -69.58 & -82.66 & -61.49 & -49.19 & -34.10 & -36.31 & -44.05 \\
\hline 10 & 1 & 3.87 & 1.10 & 2.38 & 4.16 & -6.78 & -2.40 & -8.85 & -14.36 & -6.15 & -15.00 & -8.51 & -11.15 & -5.14 \\
\hline 11 & 1 & -31.20 & -35.33 & -33.42 & -31.20 & -45.99 & -38.99 & -47.33 & -54.56 & -43.89 & -57.23 & -48.71 & -52.38 & -43.35 \\
\hline 12 & 1 & -2.01 & -1.19 & -1.67 & 2.49 & -10.53 & -16.82 & -28.47 & -37.48 & -23.12 & -19.04 & -8.61 & -10.67 & -13.09 \\
\hline 13 & 1 & 14.94 & 14.83 & 14.82 & 17.80 & 7.25 & 4.33 & -4.36 & -11.20 & -0.43 & 0.11 & 8.05 & 6.18 & 6.03 \\
\hline 14 & 1 & -7.09 & -7.84 & -7.55 & -4.16 & -17.22 & -19.13 & -29.29 & -37.39 & -24.75 & -26.25 & -16.82 & -19.30 & -18.07 \\
\hline 15 & 1 & -15.17 & -14.52 & -14.92 & -10.39 & -24.99 & -31.28 & -44.08 & -54.02 & -38.23 & -34.61 & -23.10 & -25.48 & -27.57 \\
\hline 16 & 1 & -8.85 & -9.97 & -9.51 & -6.28 & -19.42 & -20.30 & -30.16 & -38.09 & -25.79 & -28.61 & -19.37 & -21.96 & -19.86 \\
\hline 17 & 1 & 2.11 & 1.58 & 1.76 & 4.96 & -7.04 & -9.24 & -18.73 & -26.27 & -14.47 & -15.28 & -6.52 & -8.72 & -7.99 \\
\hline 18 & 1 & -31.05 & -35.18 & -33.26 & -31.05 & -45.82 & -38.81 & -47.14 & -54.36 & -43.70 & -57.05 & -48.54 & -52.21 & -43.18 \\
\hline 19 & 1 & -26.02 & -31.23 & -28.78 & -27.41 & -41.15 & -30.77 & -37.18 & -43.07 & -34.70 & -52.01 & -45.01 & -48.78 & -37.18 \\
\hline 20 & 1 & 26.97 & 20.97 & 23.92 & 22.87 & 16.05 & 30.92 & 31.13 & 30.33 & 30.59 & 9.57 & 10.67 & 7.84 & 21.82 \\
\hline 21 & 1 & -21.79 & -24.06 & -23.04 & -20.04 & -34.36 & -32.41 & -42.16 & -50.19 & -37.93 & -44.70 & -35.31 & $-38.41-3$ & .70 \\
\hline 22 & 1 & -22.30 & -24.27 & -23.40 & -20.20 & -34.69 & -33.63 & -43.82 & -52.13 & -39.36 & -45.06 & -35.34 & -38.39 & -34.38 \\
\hline 23 & 1 & -31.31 & -32.31 & -31.92 & -27.81 & -43.80 & -45.90 & -58.26 & -68.12 & -52.74 & -54.87 & -43.38 & -46.44 & -44.74 \\
\hline 24 & 1 & -29.84 & -31.16 & -30.61 & -26.75 & -42.43 & -43.55 & -55.35 & -64.83 & -50.11 & -53.39 & -42.35 & -45.44 & -42.98 \\
\hline 25 & 1 & -35.72 & -39.18 & -37.59 & -34.81 & -50.42 & -45.54 & -55.21 & -63.37 & -51.11 & -61.99 & -52.41 & -56.05 & -48.62 \\
\hline 26 & 1 & 9.11 & 7.97 & 8.46 & 11.03 & 0.13 & 0.01 & -7.97 & -14.41 & -4.45 & -7.55 & -0.03 & -2.24 & 0.00 \\
\hline 27 & 1 & 11.31 & 7.65 & 9.37 & 10.34 & 0.67 & 7.94 & 3.42 & -0.73 & 5.17 & -6.98 & -2.04 & -4.69 & 3.45 \\
\hline 28 & 1 & -32.52 & -31.88 & -32.29 & -27.15 & -43.91 & -50.81 & -65.39 & -76.73 & -58.73 & -54.98 & -41.84 & -44.60 & -46.73 \\
\hline 29 & 1 & -31.21 & -30.50 & -30.94 & -25.80 & -42.43 & -49.50 & -64.05 & -75.34 & -57.40 & -53.39 & -40.30 & -43.01 & -45.32 \\
\hline 30 & 1 & -79.68 & -79.33 & -79.63 & -72.97 & -95.50 & -103.37 & -122.49 & -137.44 & -113.80 & -110.54 & -93.21 & -97.05 & -98.75 \\
\hline 31 & 1 & -5.21 & -5.77 & -5.52 & -2.16 & -15.00 & -17.07 & -27.13 & -35.14 & -22.62 & -23.85 & -14.54 & -16.96 & -15.91 \\
\hline 32 & 1 & 29.39 & 32.94 & 31.16 & 35.83 & 25.69 & 12.70 & 0.82 & -7.91 & 6.49 & 19.97 & 30.00 & 29.16 & 20.52 \\
\hline 33 & 1 & -11.01 & -16.75 & -14.04 & -13.52 & -25.18 & -12.72 & -16.89 & -21.12 & -15.47 & -34.82 & -29.73 & -33.28 & -20.38 \\
\hline 34 & 1 & -20.46 & -22.58 & -21.63 & -18.59 & -32.80 & -31.23 & -41.04 & -49.08 & -36.77 & -43.02 & -33.62 & -36.66 & -32.29 \\
\hline 35 & 1 & -30.09 & -31.40 & -30.86 & -26.98 & -42.70 & -43.86 & -55.70 & -65.21 & -50.44 & -53.68 & -42.60 & -45.69 & -43.27 \\
\hline 36 & 1 & 5.22 & 3.64 & 4.34 & 6.79 & -4.43 & -3.46 & -11.29 & -17.69 & -7.87 & -12.47 & -4.98 & -7.36 & -4.13 \\
\hline 37 & 1 & -31.21 & -30.50 & -30.94 & -25.80 & -42.43 & -49.50 & -64.05 & -75.34 & -57.40 & -53.39 & -40.30 & -43.01 & -45.32 \\
\hline 38 & 1 & -18.45 & -13.24 & -15.86 & -8.47 & -25.20 & -44.88 & -63.86 & -77.90 & -54.84 & -34.84 & -18.70 & -20.26 & -33.04 \\
\hline 39 & 1 & 18.34 & 11.70 & 14.87 & 13.79 & 6.13 & 22.33 & 22.35 & 21.28 & 21.80 & -1.10 & 0.36 & -2.73 & 12.43 \\
\hline 40 & 1 & 2.76 & 2.63 & 2.62 & 6.03 & -6.04 & -9.36 & -19.29 & -27.11 & -14.80 & -14.20 & -5.12 & -7.27 & -7.43 \\
\hline 41 & 1 & -11.01 & -16.75 & -14.04 & -13.52 & -25.18 & -12.72 & -16.89 & -21.12 & -15.47 & -34.82 & -29.73 & -33.28 & -20.38 \\
\hline 42 & 1 & -30.24 & -31.31 & -30.88 & -26.86 & -42.69 & -44.51 & -56.66 & -66.37 & -51.25 & -53.67 & -42.36 & -45.41 & -43.52 \\
\hline 43 & 1 & -17.90 & -19.46 & -18.79 & -15.50 & -29.61 & -29.57 & -39.82 & -48.12 & -35.30 & -39.58 & -29.89 & -32.77 & -29.69 \\
\hline 44 & 1 & -19.98 & -22.76 & -21.49 & -18.86 & -32.77 & -29.27 & -38.18 & -45.63 & -34.37 & -42.99 & -34.25 & -37.41 & -31.50 \\
\hline 45 & 1 & 6.83 & 8.07 & 7.40 & 11.49 & -0.59 & -7.74 & -19.01 & -27.65 & -13.81 & -8.33 & 1.65 & -0.13 & -3.49 \\
\hline 46 & 2 & -36.99 & -40.45 & -38.72 & -36.15 & -51.66 & -50.23 & -63.26 & -73.92 & -57.33 & -63.34 & -54.45 & -58.37 & -52.07 \\
\hline 47 & 2 & -85.19 & -104.92 & -95.27 & -100.84 & -116.16 & -70.13 & -68.17 & -69.70 & -70.28 & -132.79 & -134.91 & -143.16 & -99.29 \\
\hline 48 & 2 & -6.09 & -0.42 & -3.57 & 4.20 & -11.69 & -24.89 & -36.23 & -44.50 & -31.30 & -20.29 & -3.16 & -3.80 & -15.14 \\
\hline 49 & 2 & 6.18 & 6.34 & 6.03 & 9.78 & -2.26 & -2.35 & -8.55 & -13.56 & -6.09 & -10.13 & -0.15 & -1.87 & -1.39 \\
\hline 50 & 2 & 3.67 & 5.05 & 4.28 & 8.61 & -3.96 & -11.08 & -22.32 & -30.94 & -17.17 & -11.96 & -1.40 & -3.18 & -6.70 \\
\hline 51 & 2 & -27.31 & -25.81 & -26.83 & -21.01 & -37.78 & -42.30 & -52.98 & -61.32 & -48.45 & -48.39 & -33.80 & -35.92 & -38.49 \\
\hline 52 & 3 & 5.80 & 2.54 & 4.34 & 5.29 & -4.78 & -8.47 & -25.08 & -38.72 & -16.61 & -12.84 & -8.26 & -11.28 & -9.01 \\
\hline 53 & 3 & -16.90 & -16.86 & -17.07 & -12.67 & -27.43 & -29.11 & -38.37 & -45.70 & -34.46 & -37.24 & -25.55 & -27.91 & -27.44 \\
\hline 54 & 3 & -4.27 & -11.03 & -7.86 & -8.11 & -18.64 & -2.96 & -5.83 & -9.37 & -4.96 & -27.77 & -23.91 & -27.37 & -12.67 \\
\hline 55 & 3 & 5.01 & 6.40 & 5.63 & 9.91 & -2.49 & -9.52 & -20.55 & -28.99 & -15.50 & -10.37 & 0.05 & -1.70 & -5.18 \\
\hline 56 & 4 & 62.24 & 69.55 & 66.35 & 72.03 & 65.67 & 43.62 & 25.04 & 12.90 & 32.07 & 61.39 & 70.09 & 69.88 & 54.23 \\
\hline 57 & 5 & -346.90 & -271.42 & -306.65 & -248.14 & -329.42 & -625.25 & -841.60 & -1003.32 & -728.58 & -362.47 & -257.85 & -255.31 & -464.74 \\
\hline 58 & 6 & 30.70 & 27.59 & 29.02 & 29.69 & 22.17 & 29.43 & 27.12 & 24.79 & 27.82 & 16.18 & 19.98 & 17.91 & 25.20 \\
\hline 59 & 7 & 62.54 & 64.09 & 63.31 & 65.59 & 60.33 & 54.37 & 48.47 & 44.10 & 51.27 & 57.28 & 62.30 & 61.79 & 57.95 \\
\hline 60 & 8 & 0.51 & 3.15 & 1.75 & 6.98 & -6.48 & -16.78 & -29.18 & -38.46 & -23.49 & -14.68 & -2.56 & -4.15 & -10.28 \\
\hline 61 & 9 & 21.47 & 19.99 & 20.56 & 22.65 & 13.27 & 17.27 & 14.02 & 11.29 & 15.04 & 6.59 & 13.10 & 11.24 & 15.54 \\
\hline 62 & 10 & -11.59 & -12.94 & -12.31 & -9.22 & -22.52 & -24.04 & -35.01 & -43.79 & -30.05 & -31.95 & -22.97 & -25.77 & -23.51 \\
\hline 63 & 11 & -24.49 & -25.69 & -25.20 & -21.46 & -36.52 & -37.78 & -49.18 & -58.32 & -44.11 & -47.03 & 36.38 & -39.32 & -37.12 \\
\hline
\end{tabular}

\section{Conclusion}

The performance of 63 sunshine-based models of different functional forms was evaluated for predicting the monthly global solar radiation on the horizontal surface for Lagos, Nigeria. The authors observed that 49 models performed poorly with respect to both monthly and annual data after applying relative percentage error analysis while 14 models exhibited better performances. The 14 models were subjected to further statistical analysis by employing regression analysis, MBE, MPE and RMSE. At the end of the analysis model 49 yielded the lowest MBE, MPE, RMSE and highest coefficient of correlation values which is recommended by solar energy researchers for obtaining optimal solar system.

\section{Acknowledgements}

Our thanks go to all the authors cited in this paper for their research works that has made this research possible. 


\section{Funding}

This research did not receive any specific grant from funding agencies in the public, commercial, or not-for-profit sectors.

\section{References}

[1] Khorasanizadeh H, Mohammadi. Diffuse solar radiation on a horizontal surface: Reviewing and categorizing the empirical models. Renewable and Sustaining Energy Reviews, 2016, 53: 338-362. https://doi.org/10.1016/j.rser.2015.08.037.

[2] Thirugnanasasambandam M, Iniyan S, Goic A. A review of solar thermal technologies. Renewable and Sustainable Energy Reviews, 2010, 14: 312-322. https://doi.org/10.1016/j.rser.2009.07.014.

[3] Ullah KR, Saidur R, Ping HW, Akikur RK, Shuvo NH. A review of solar thermal refrigeration and cooling methods. Renewable and Sustainable Energy Review, 2013, 24: 499-513. https://doi.org/10.1016/j.rser.2013.03.024.

[4] Besharat F, Dehghan A, Faghih AR. Empirical models for estimating global solar radiation: A review and case study. Renewable and Sustainable Energy Review, 2013, 21: 798-821. https://doi.org/10.1016/j.rser.2012.12.043.

[5] Yaniktepe B, Gene YA. Estimating new model for predicting the global solar radiation on horizontal surface. International Journal of Hydrogen, 2015, 40:

15278-15283. https://doi.org/10.1016/j.ijhydene.2015.02.064.

[6] Li H, Bu X, Long Z, Zhao L, Ma W. Calculating the diffuse solar radiation in regions without solar radiation measurements. Energy, 2012, 44: 611-615. https://doi.org/10.1016/j.energy.2012.05.033.

[7] Muneer T, Munawwar S. Improved accuracy models for hourly diffuse solar radiation. Journal of Solar Energy Engineering, 2006, 128: 104-117. https://doi.org/10.1115/1.2148972.

[8] Ertekin C, Yaldiz O. Estimating of monthly average daily global radiation on horizontal surface for Antalya, Turkey. Renewable Energy, 1999, 17: 95-102. https://doi.org/10.1016/S09601481(98)00109-8.

[9] Nwokolo SC, Ogbulezie JC, Toge CK, John-Jaja SA, Modeling the influence of relative humidity on photosynthetically active radiation from global horizontal irradiation in six tropical ecological zones in Nigeria. New York Science Journal, 2016, 9: 40-55

[10] Nwokolo S.C, Ogbulezie J.C. (2017). A single parameter basedmodel for calibrating Hargreaves-Samani coefficient in Nigeria. International Journal of Physical Research, 5 (2): 49-59 https://doi.org/10.14419/ijpr.v5i2.8042.

[11] Nwokolo, S.C., \& Ogbulezie, J.C., (2017). A Quantitative Review and Classification of Empirical Models for Predicting Global Solar Radiation in West Africa. Beni-Suef University Journal of Basic and Applied Sciences, (In Press). https://doi.org/10.1016/j.bjbas.2017.05.001.

[12] Nwokolo, S.C. (2017). A comprehensive review of empirical models for estimating global solar radiation in Africa. Renewable and Sus-tainable Energy Reviews, 78: 955-995 https://doi.org/10.1016/j.rser.2017.04.101.

[13] Angstrom, A. Solar and terrestrial radiation. Quarterly Journal of Royal Meteorological Society 1924; 50: 121-5. https://doi.org/10.1002/qj.49705021008.

[14] Prescott JA. Evaporation from water surface in relation to solar radiation. Transactions of the Royal Society of Australia, 1940, 48: 114-8.

[15] Ododo JC. New models for the prediction of solar radiation in Nigeria. Paper presented at the 2nd OAU/STRC conference on New Renewable and Solar Energies at Bamako, Mali, 1994, 16-20

[16] Halouani M, Nguyen CT, Vongoc D. Calculation of monthly average global solar radiation on horizontal surface using daily hours of bright sunshine. Solar Energy, 1993, 50: 247-255 https://doi.org/10.1016/0038-092X(93)90018-J.

[17] Ituen EE, Esen NU, Nwokolo SC, Udo EG. Prediction of global solar radiation using relative humidity, maximum temperature and sunshine hour in Uyo, in the Niger Delta region, Nigeria. Advances in Applied Science Research, 2012, 3: 1923-1937.

[18] Akpabio LE, Etuk SE. Empirical correlation of global solar radiation with meteorological data for Onne, Nigeria. Turkish Journal of Physics, 2003, 28: $222-227$

[19] Rietveld M. A new method for estimating the regression coefficients in the formula relating solar radiation to sunshine. Agricultural Meteorology, 1978, 19:243-252 https://doi.org/10.1016/00021571(78)90014-6.
[20] Akpabio LE, Udo SO, Etuk SE. Empirical correlation of global solar radiation with meteorological data for Onne, Nigeria. Turkish Journal of Physics, 2005, 28: $222-227$

[21] Falayi EO, Rabiu AB. Modeling global solar radiation using sunshine duration data. Nigeria Journal of Physics 2005, 17:181-186

[22] Maduekwe AAL, Chendo MAC. Predicting the components of the total hemispherical solar radiation from sunshine duration measurement in Lagos, Nigeria. Renewable Energy, 1995, 6: 807-812 https://doi.org/10.1016/0960-1481(95)91008-2.

[23] Kholagi A, Ramadan MRI, Ali ZEH, Fattah YA. Global and Diffuse solar irradiation in Yemen (Y.A.R). Solar Energy, 1983, 31: 35-62

[24] Friend AD. Parameterization of a global daily weather generator for terrestrial ecosystem modeling. Ecological Modelling, 1998, 109: 121-140 https://doi.org/10.1016/S0304-3800(98)00036-2.

[25] Turton SM. The relationship between total irradiation and sunshine in humid tropics. Solar Energy, 1986, 38: 353-354 https://doi.org/10.1016/0038-092X(87)90007-7.

[26] Ezekwe CI, Ezeifo CCO. Measured solar radiation in a Nigerian environment compared with predicted data. Solar Energy, 1981, 26: 181-6. https://doi.org/10.1016/0038-092X(81)90083-9.

[27] Ezeilo CCO. Solar radiation measurements. The Nigerian experience in the proceedings of the National Symposium on Solar Energy, held at Sokoto State Polytechnic, Benin-Kebbi, Nigeria (2nd to 3rd November), 1982.

[28] Arinze EA. Obi SE. Solar energy availability and prediction in Northern Nigeria. Solar Energy, 1984, 3: 3-10.

[29] Sambo AS. Solar radiation in Kano - a correlation with meteorological data. Nigeria Journal of Solar Energy, 1985, 1-59-65.

[30] Folayam CO, Ogunbiyi A. Estimating global solar radiation in Samaru. Presented at the SESN National Solar Energy Forum, held at Zaira, 25th June, 1986.

[31] Sambo AS. Empirical models for the correlation of global solar radiation with meteorological data for northern Nigeria. Solar Wind Technology, 1986, 3: 89-93. https://doi.org/10.1016/0741983X(86)90019-6.

[32] Fagbenle RO. Estimation of total radiation in Nigeria using meteorological data. Nigerian Journal of Renewable Energy, 1990, 1: 1-10.

[33] Kuye A, Jagtap SS. Analysis of solar radiation data for PortHarcourt, Nigeria. Solar Energy, 1992, 49:139-45. https://doi.org/10.1016/0038-092X(92)90148-4.

[34] Akinbode FO. Solar radiation in Minna: Correlation with meteorological data. Nigeria Journal of Renewable Energy, 1992, 3: 9-17.

[35] Fagbenle RO. Total solar radiation estimates in Nigeria using a maximum likelihood quadratic fit. Renewable Energy, 1993, 33: 827-31. https://doi.org/10.1016/0960-1481(93)90089-Y

[36] Burari, FW, Sambo AS. Alternative model for the determination of angstrom coefficients for Bauchi. Nigerian Journal of Renewable Energy, 2000, 8: 66-68.

[37] Falayi Eo, Adepitan JO, Rabiu AB. Empirical models for the correlation of global solar radiation with meteorological data for Iseyin, Nigeria. International Journal of Physical Science, 2008, 3: 210-216.

[38] Tijjani BI. Comparison between first and second order Angstrom type models for sunshine hours at Katisna, Nigeria. Bayero Journal of Pure and Applied Sciences, 2011, 4: 24-27.

[39] Yohanna JK, Itodo IS, Umogba VI. A model for determining the global solar radiation in Warri, Nigeria. Pacific Journal of Science and Technology, 2009, 10: 574-9.

[40] Adaramola MS. Estimating global solar radiation using common meteorological data in Akura, Nigeria. Renewable Energy, 2012, 47 38-44. https://doi.org/10.1016/j.renene.2012.04.005.

[41] Yakubu D, Medugu DW. Relationship between the global solar radiation and the sunshine duration in Abuja, Nigeria. Ozean Journal of Applied Sciences, 2012, 5: 221-228.

[42] Musa B, Zangina U, Aminu M. Estimation of global solar radiation in Maiduguri, Nigeria using Angstrom model. APRN Journal of Engineering and Applied Sciences, 2012, 7: 1623-1627.

[43] Kolebaje OT, Mustapha LO. On the performance of some predictive models for global solar radiation estimates in tropical stations: Port Harcourt and Lokoja, 2012, 7: 145-163.

[44] Ohunakin OS, Adaramola MS, Oyewolu OM, Fagbenle RO. Correlations for estimating solar radiation using sunshine hours and temperature measurement in Osogbo, Osun State, Nigeria. Frontier in Energy, 2013, 1-9. Doi. 1007/511708-013-0241-2.

[45] Solomon A. Evaluation of the regression parameters of the angstrom-page model for predicting global solar radiation. Journal of energy in Southern Africa, 2013, 24: 46-49.

[46] Gana NN, Akpootu DO. Estimation of global solar radiation using four sunshine based models in Kebbi, North-Western, Nigeria. Advances in Applied Science Research, 2013, 4: 409-421. 
[47] Medugu DW, Burari FW, Abdul'Azaz MA. Measurement of incoming solar radiation: comparison of data obtained from a constructed reliable pyranometer (Rmpool) and a high quality pyranometer (CMP3) under varying climatic condition at Mubi, Nigeria. Archives of Physics Research, 2013, 1: 129-146.

[48] Isikwue B, Dandy S, Audu M. Testing the performance of some empirical models for estimating global solar radiation over Makurdi, Nigeria. Journal of Natural Sciences Research, 2013, 3: 165-170.

[49] Okonkwo GN. Nwokoye AOC. Development of models for predicting global solar radiation in Minna, Nigeria using meteorological data. IOSR Journal of Applied Physics, 2014, 6: 01-06.

[50] Ogolo EO. Estimation of global solar radiation in Nigeria using a modified Angstrom model and the trend analysis of the allied meteorological components. Indian Journal of Radio \& Space Physics, 2014, 43: 213-224.

[51] Nwokoye AOC, Okonkwo GN. Testing the predictive efficiencies of four Angstrom-type models for estimating solar radiation in Bida, Nigeria, IOSR Journal of Applied Physics, 2014, 6: 15-16.

[52] Kaltiya MS, Abubakar MS, Itodo IN. Predictive of global solar radiation using Angstrom-page equation model for Makurdi, Benue State, Nigeria. American Journal of Engineering Research, 2014, 3: 145-150.

[53] Sheriff MA, Goje AA, Zannah MW. Estimation of global solar radiation using sunshine duration in Maiduguri, Nigeria. Nigerian Journal of Physics, 2014, 25: 35-39.

[54] Ike CU. Global solar radiation in Awka, South East, Nigeria using weather station. APRN Journal of Sciences and Technology, 2014, 4: 678-683.

[55] Gana NN, Jitendru KR, Momoh M. Angstrom constants for estimating solar radiation using four sunshine based models in Kebbi, North-Western, Nigeria. International Journal of Scientific and Engineering Research, 2014, 5: 1636-1647.

[56] Sani GD, Mohd ET, Mohd BG, Usman MG, Musa GA. The correlation functions and estimation of global solar radiation studies using sunshine base model for Kano, Nigeria. Advances in Physics Theories and Application, 2015, 39: 55-61.

[57] Adesina MA, Ibrahim JS, Ponzi UD. A model for predicting solar radiation for Nasarawa, Nigeria. International Journal of Modern Engineering Sciences, 2015, 4: 22-30.

[58] Olatona, GI, Adeleke AE. Estimation of solar radiation over Ibadan from routine meteorological parameters. The International Journal of Engineering and Science, 2015, 4: 44-51.

[59] Okonkwo GN. Nwokoye AOC. Development of models for predicting global solar radiation in Minna, Nigeria using meteorological data. IOSR Journal of Applied Physics, 2014, 6: 01-06.

[60] Innocent AJ, Jacob OE, Chibuzo GC, James I, Odeh DO. Estimation of global solar radiation in Gusua, Nigeria. International Journal of Research in Engineering and Technology, 2015, 3:27-32.

[61] Boluwaji MO, Onyedi DO. Comparative study of ground measured satellite-derived, and estimated global solar radiation data in Nigeria. Journal of Solar Energy, 2016, 10: 1-7.

[62] Okundamiya MS, Emagbethre JO, Ogujor EA. Evaluation of various global solar radiation models for Nigeria. International Journal of Green Energy, 2016, 13: 505-512. https://doi.org/10.1080/15435075.2014.968921.

[63] Ayodele TR, Ogunjuyigbe. Performance assessment of empirical models for prediction of daily and monthly average global solar radiation: the case study of Ibadan, Nigeria. International Journal of Ambient Energy, 2016; Doi: 10.1080/01430750.2016.

[64] Udo SO. Contribution to the relationship between solar radiation and sunshine duration in the tropics: A case study of experimental data in Ilorin, Nigeria. Turkish Journal of Physics, 2002, 16: 123 130

[65] Lewis G. An empirical relation for estimating dependent global insolation model for Tennessee, USA. Energy Conversion and Management, 1992, 33: 1097-9 https://doi.org/10.1016/01968904(92)90007-J.

[66] Tahran S, Sari A. Model selection for global and diffuse radiation over the central Black Sea (CBS) region of Turkey, Energy Conversion and Management, 2005, 46: 605-613 https://doi.org/10.1016/j.enconman.2004.04.004.

[67] Burari FW, Abduluzeer M, Sulaiman MN. Mathematical models for the prediction of global solar radiation for Maiduguri, Nigeria. Nigerian Journal of Tropical Engineering, 2006, 6: 32-37.

[68] Togrul IT, Togrul H. Global Solar Radiation over Turkey: comparison of predicted and measured data. Renewable Energy, 2002, 25 55-67 https://doi.org/10.1016/S0960-1481(00)00197-X

[69] Ulgen K, Hepbasli A. Solar radiation models. Part 2: Comparison and developing new models. Solar Sources, 2004, 26: 521-530 https://doi.org/10.1080/00908310490429704.
[70] Glover J, McGulloch JSG. The empirical relation between solar radiation and hours of sunshine.

[71] Iqbal M. Prediction of hourly diffuse solar radiation from measured hourly global solar radiation on a horizontal surface. Solar Energy, 1980, 24: 491-503 https://doi.org/10.1016/0038-092X(80)90317-5.

[72] Guild to meteorological instruments and methods of observation 7th ed. Geneva: World Meteorological Organization, 2008

[73] Menges HO, Ertekin C, Sonmete MH. Evaluation of global solar radiation models for Konya, Turkey. Energy Conversion and Management, 2006, 47: 3149-3173 https://doi.org/10.1016/j.enconman.2006.02.015.

[74] Robaa Sm. Validation of the existing models for estimating global solar radiation over Egypt. Energy Conversion and Management, 2009, 50: 184-193 https://doi.org/10.1016/j.enconman.2008.07.005.

[75] Al-Mostafa ZA, Maghrabi AH, Al-Shehri SM. Assessment of Sunshine-based global radiation models using data measured in Riyadh, Saudi Arabia. Journal of Energy Institute, 2012, 1: 14-21 https://doi.org/10.1179/174396711X13116932752038.

[76] Al-Mostafa ZA, Maghrabi AH, Al-Shehri SM. Sunshine-based global radiation models: A review and case study. Energy Conversion and Management, 2014. 84: 209-216 https://doi.org/10.1016/j.enconman.2014.04.021. 